\title{
SISTEM INFORMASI MANAJEMEN UNTUK MENINGKATKAN DAYA SAING INDUSTRI RUMAH TANGGA
}

\author{
Al Fath Riza Kholdani ${ }^{1)}$, Desy Ika Puspitasari ${ }^{2)}$ \\ ${ }^{1}$ FAKULTAS TEKNOLOGI INFORMASI \\ UNIVERSITAS ISLAM KALIMANTAN MAB BANJARMASIN \\ Email : kholdanialfath@gmail.com \\ ${ }^{2}$ FAKULTAS TEKNOLOGI INFORMASI \\ UNIVERSITAS ISLAM KALIMANTAN MAB BANJARMASIN \\ Email : smile4desyka@gmail.com
}

\begin{abstract}
ABSTRAK
Para pengrajin kerajinan tangan memiliki kelemahan dalam hal pengelolaan pemasaran, masih bersifat tradisional, artinya mereka dagangkan secara langsung. Padahal diluaran sana mungkin saja banyak orang yang memerlukan atau mencari kerajinan tangan tersebut baik dikoleksi untuk pribadi maupun dijadikan sebagai hadiah. Sisi lain adalah keterbatasannya tempat perdagangan yang sangat mempengaruhi terhadap jumlah industri dan penjualan. Sistem informasi manajemen membantu pengelolaan barang yang akan dipasarkan oleh pengrajin berbasis online atau e-commerce. Ecommerce adalah kegiatan komersil dalam pemasaran baik barang maupun jasa, proses jual beli dan kegitan perdagangan lainnya melalui sistem elektronik salah satunya berbasis web. Sistem informasi manajemen tersebut membuat pelaku bisnis memanfaatkannya dalam meningkatkan strategi pemasaran dan persaingan bisnis serta pengelolaan jual beli yang terkomputerisasi. Keamanan dan kualitas barang dagangan online masih banyak terdapat kasus ketidak sesuaian antara ekspektasi pembeli dengan barang yang telah dibeli. Salah satu cara untuk menekan beberapa ketidak pastian tersebut adalah datang langsung menemui penjual seperti halnya yang telah dilakukan oleh web ECommerce OLX.com, tetapi jika jarak antara pembeli dan penjualan berjauhan menjadi percuma. Begitupun halnya dengan web E-Commerce bukalapak.com, ada fasilitas tawar menawar barang dagangan tetapi itupun hanya lewat teks.
\end{abstract}

Kata Kunci : aplikasi, e-commerce, sistem informasi manajemen

\section{PENDAHULUAN}

Teknologi informasi menjadikan semua hal jadi lebih rinci, rapi, cepat dan tepat. Pengelolaan jual beli secara terkomputerisasi membuat proses manajemen pemasaran meningkatkan daya saing industri. suatu Keamanan dan kualitas barang dagangan online masih banyak terdapat kasus ketidak sesuaian antara ekspektasi pembeli dengan barang yang telah dibeli. Salah satu cara untuk menekan beberapa ketidak pastian tersebut adalah datang langsung menemui penjual seperti halnya yang telah dilakukan oleh $E$ Commerce OLX.com, tetapi jika jarak antara pembeli dan penjualan berjauhan menjadi percuma. Begitupun halnya dengan bukalapak.com, ada fasilitas tawar menawar barang dagangan tetapi itupun hanya lewat teks. Sistem informasi manajemen yang dibangun nantinya memiliki fasilitas video call.

Para pengrajin kerajinan tangan memiliki kelemahan dalam hal pemasaran, masih bersifat tradisional, artinya mereka dagangkan secara langsung. Padahal diluaran sana mungkin saja banyak orang yang memerlukan atau mencari kerajinan tangan tersebut baik dikoleksi untuk pribadi maupun dijadikan sebagai hadiah. Sisi lain adalah keterbatasannya tempat perdagangan yang sangat mempengaruhi terhadap jumlah industri dan penjualan.

Pembangunan Sistem Informasi Manajemen Untuk Meningkatkan Daya Saing Industri Rumah Tangga, Selain dapat melihat barang dagangan secara langsung barang yang dipasarkan (dalam video atau video call), pembeli juga dapat berbicara secara tatap muka dengan penjual, menjadikan sistem 
informasi manajemen berbasis e-commerce layaknya pasar umum. Pengrajin yang memasarkan barang dagangannya juga bisa memanfaatkan rincian transaksi perdagangan yang mereka dagangkan.

Tujuan penelitian ini adalah mengurangi berbagai resiko pemasaran online atau $E$ Commerce bagi masyarakat untuk melihat secara langsung barang dagangan yang dipasarkan dan dapat melakukan tatap muka baik untuk diskusi maupun tawar menawar dengan penjual. Pengelolaan pada proses perdagangan secara terkomputerisasi melalui sistem informasi manajemen.

\section{METODE PENELITIAN}

Studi kasus pada penelitian ini dengan pendekatan perluasan pasar menggunakan analisa kesempatan sasaran pemasaran, perancangan model sistem, fasilitas antarmuka pelanggan, komunikasi pasar dan rancangan implementasi. Instrumen penelitian menggunakan teknik wawancara dan observasi serta studi pustaka. Pengambilan sampel menggunakan teknik purposive sampling. Data penelitian ini berasal data primer dan data sekunder. Perancangan aplikasinya menggunakan pendekatan Waterfall. Pendekatan ini merupakan model klasik dan bersifat sistematis sehingga mudah memahaminya karena semua prosesnya bekerja secara berurutan dalam tahapan membangun sebuah perangkat lunak.

Tahapan penerapan e-commerce dilakukan melalui kegiatan survei, analisis, perancangan, pembuatan sistem, implementasi dan pemeliharaan. Survei bertujuan untuk mengetahui ruang lingkup keperluan pasar berdasarkan kebutuhan. Analisis bertujuan untuk memahami sistem yang ada, mengidentifikasi masalah dan memecahkan menjadi solusi. Perancangan bertujuan mendesain sebuah sistem baru untuk menyelesaikan masalah-masalah yang dihadapi oleh para pengguna aplikasi e-commerce. Pembuatan sistem bertujuan menghasilkan sebuah sistem baru melalui sistem pengkodean komputerisasi menghasilkan interface yang user friedly. Implementasi bertujuan agar sistem yang dihasilkan dapat memberikan manfaat mengatasi persoalan yang terjadi dan menyelesaikan kelemahan yang terjadi pada aplikasi $e$-commerce lainnya.
Untuk penerapannya menggunakan cara secara berurutan (waterfall), dimana setiap tahapan harus diselesaikan terlebih dahulu secara penuh sebelum meneruskan ke tahapan berikutnya, dengan tujuan menghindari terjadinya pengulangan tahapan tersebut. Pemeliharaan bertujuan agar sistem dapat berjalan atau dioperasionalkan secara optimal dan sesuai fungsinya. Tahap evaluasi dilakukan untuk memastikan bahwa pelaksanaan pengembangan sistem sesuai dengan rencana yang telah ditetapkan baik dari segi waktu, biaya maupun secara teknis.

\section{Gambar 1. Metode Waterfall}

Perancangan sistem basis data menggunakan metode pendekatan terstruktur. Metode ini lebih menekankan pada aliran data, yaitu Data Flow Diagram (DFD).

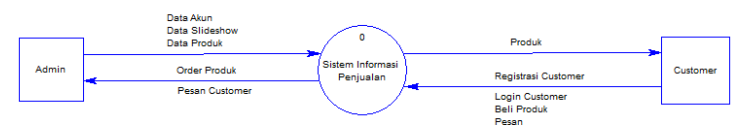

Gambar 2. Diagram Konteks

Perancangan relasi antar tabel digunakan untuk merepresentasikan hubungan suatu tabel ke tabel lainnya yang berfungsi untuk mengatur operasi basis data.

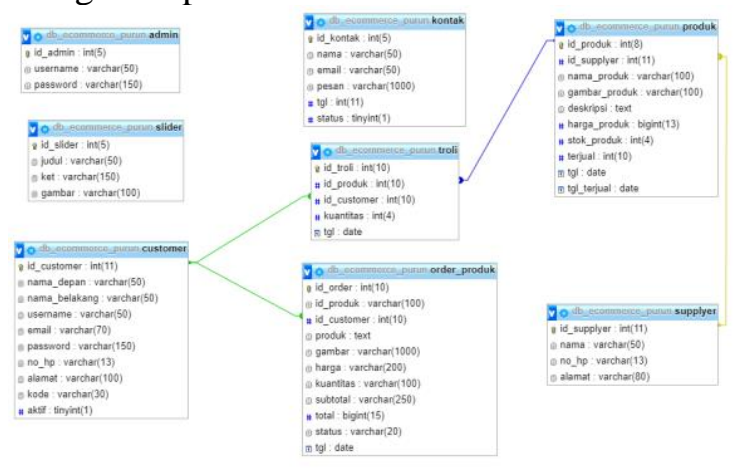

Gambar 3. Relasi Antar Tabel

\section{PEMBAHASAN}

Halaman utama pertama kali diakses oleh customer ketika mengunjungi website ecommerce ini dapat di akses di website kholdani.com. 


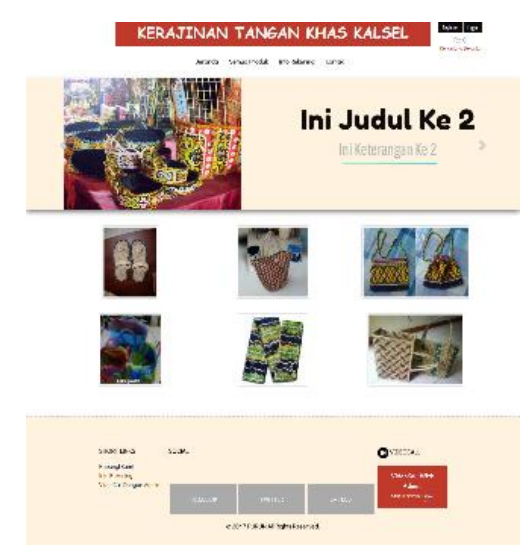

Gambar 4. Halaman Utama

\section{A. Halaman Produk}

Halaman produk berfungsi untuk menampilkan semua list produk dan juga dapat melakukan pencarian produk yang diinginkan.

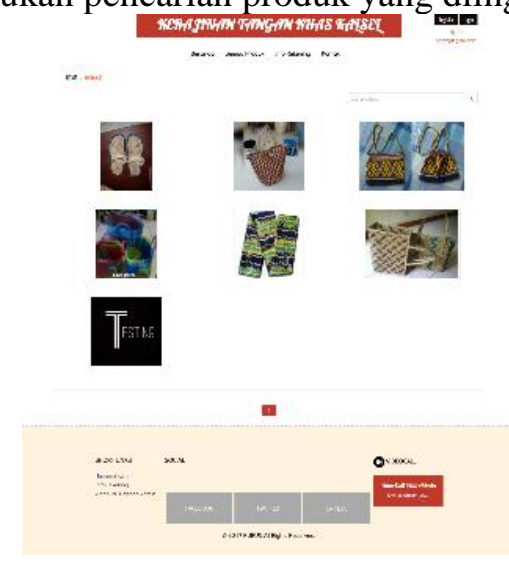

Gambar 5. Halaman Produk

\section{B. Halaman Detail Produk}

Halaman detail produk berfungsi untuk menampilkan detail dari produk, diantaranya adalah harga, stok, qty, gambar, nama produk, dan deskripsi produk.
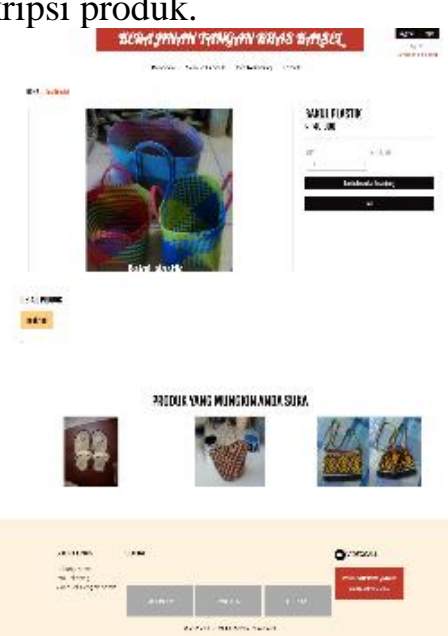

Gambar 6. Halaman Detail Produk

\section{Halaman Keranjang Belanja}

Halaman keranjang belanja berfungsi untuk menampilkan daftar belanja customer.

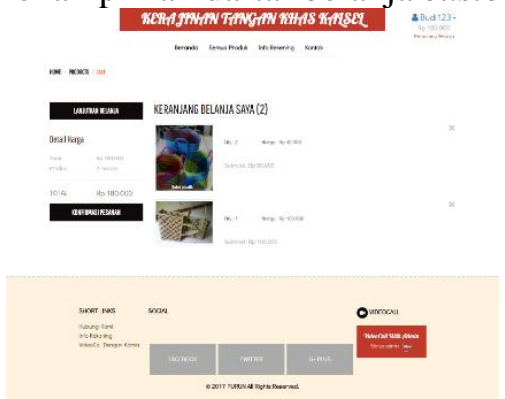

Gambar 7. Halaman Keranjang Belanja

\section{Halaman Kontak}

Halaman kontak berfungsi untuk customer mengirim pesan kepada admin.

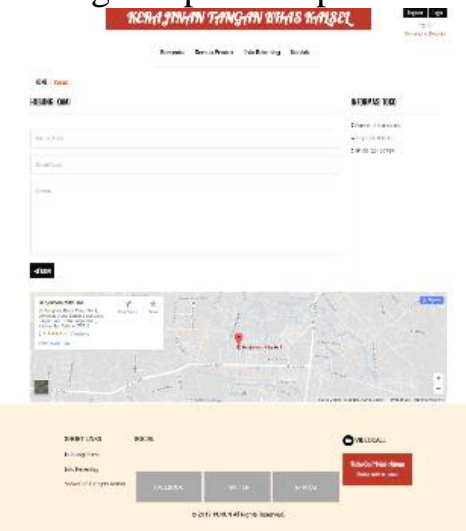

Gambar 8. Halaman Kontak

\section{E. Halaman Login}

Halaman login berfungsi untuk login customer, customer dapat berbelanja ketika sudah melakukan login.

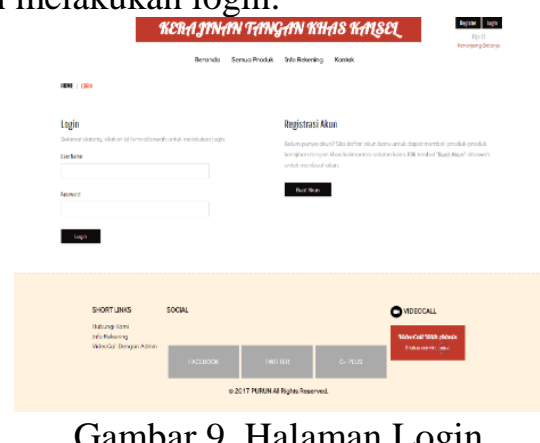

\section{F. Halaman Videocall}

Halaman videocall berfungsi untuk berkomunikasi secara langsung menggunakan videocall antara customer dan admin. 


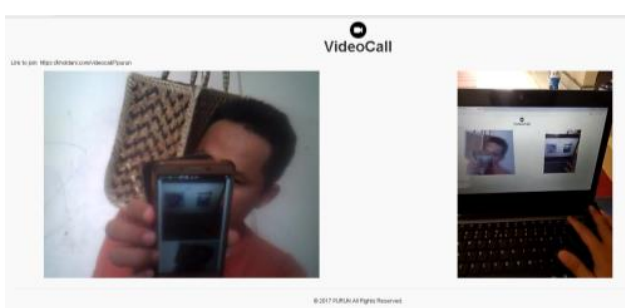

Gambar 10. Halaman Videocall

\section{G. Pop-up Pesanan Saya}

Pop-up pesanan saya berfungsi untuk menampilkan informasi produk yang dipesan oleh customer.

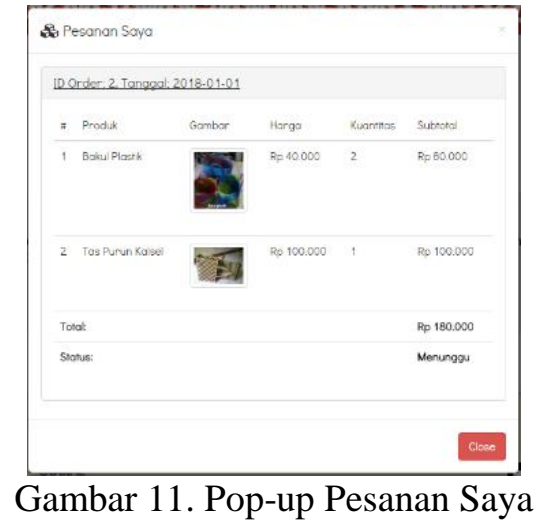

\section{H. Form Login Admin}

Form login akan muncul pada saat pertama kali aplikasi dijalankan. Form login digunakan sebagai sistem keamanan user. Pada saat menuju ke halaman utama user wajib mengisi username dan password yang ada pada form login.

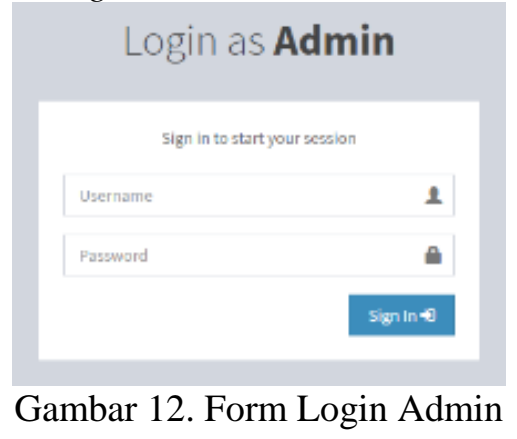

Apabila user memasukkan username dan password yang benar maka setelah mengklik tombol log in akan langsung menuju halaman utama.

\section{Halaman Dashboard \\ Halaman Dashboard dapat diakses} ketika user berhasil login.

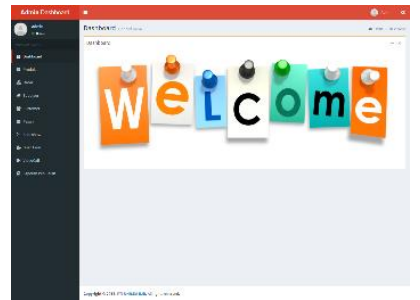

Gambar 13. Halaman Dashboard

\section{J. Halaman Data Produk}

Halaman ini dirancang untuk mengolah data produk yang berisi tabel dan form produk. Form produk terdiri dari produk, foto, harga, stok, dan deskripsi produk.

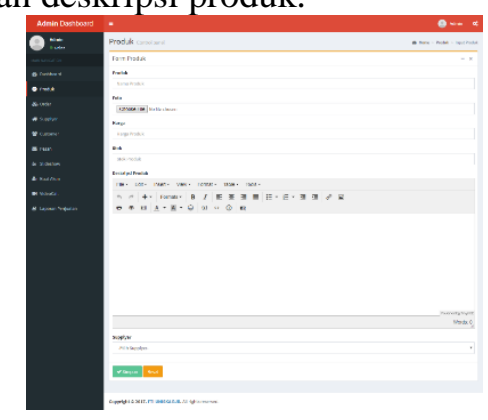

Gambar 14. Halaman Data Produk

\section{K. Halaman Data Order}

Halaman ini dirancang untuk mengolah data order produk yang dipesan oleh customer.

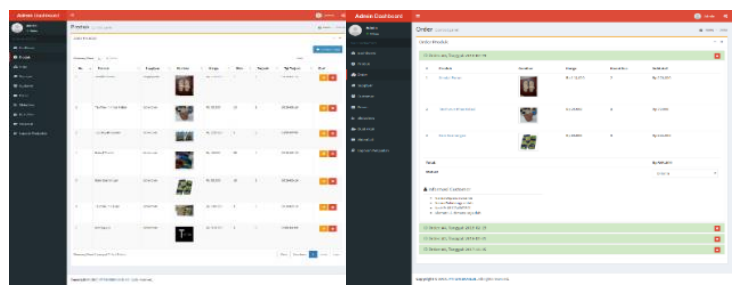

Gambar 15. Halaman Data Order

\section{Halaman Data Supplyer}

Halaman ini dirancang untuk mengolah data supplyer yang berisi tabel dan form supplyer. Form supplyer terdiri dari nama supplyer, no hp dan alamat.

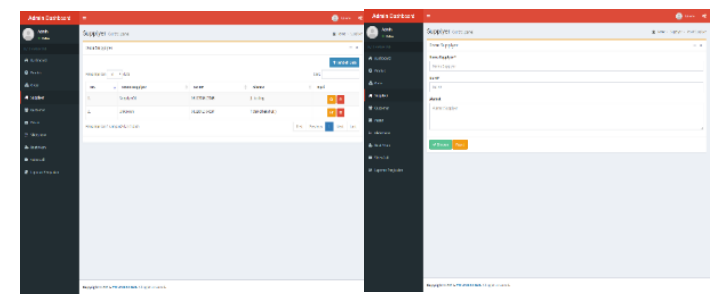

Gambar 16. Halaman Data Supplyer 


\section{Laporan Penjualan}

Laporan penjualan baik harian, mingguan, bulanan maupun tahunan hasil dari supplier.

\begin{tabular}{|c|c|c|c|c|c|}
\hline No. & Produk & Supplyer & Harga & Qty & Subtotal \\
\hline 1. & Bakul Plastik & Unknown & Rp 40.000 & 2 & Rp 80.000 \\
\hline 2. & Tas Purun Kalsel & Unknown & Rp 100.000 & 1 & Rp 100.000 \\
\hline 3. & Sendal Purun & Supplyer01 & Rp 110.000 & 2 & Rp 220.000 \\
\hline 4. & Tas Purun Khas Kalsel & Unknown & Rp 35.000 & 2 & Rp 70.000 \\
\hline 5. & Kain Sasirangan & Unknown & Rp 85.000 & 3 & Rp 255.000 \\
\hline 6. & Bakul Plastik & Unknown & Rp 40.000 & 1 & Rp 40.000 \\
\hline \multicolumn{5}{|l|}{\begin{tabular}{|l|} 
Total: \\
\end{tabular}} & Rp 765.000 \\
\hline
\end{tabular}

Gambar 17. Halaman Laporan Penjualan

\section{PENGUJIAN DAN HASIL}

Hasil yang akan didapat dari penelitian ini dilakukan melalui beberapa metode pengujian yaitu dengan metode Black Box dan User Acceptance. Pengujian black Box adalah pengujian yang dilakukan hanya mengamati hasil eksekusi melalui data uji dan memeriksa fungsional dari perangkat lunak, sedangkan User Acceptance adalah suatu proses pengujian oleh pengguna yang dimaksudkan untuk menghasilkan dokumen yang dijadikan bukti bahwa software yang telah dikembangkan telah dapat diterima oleh pengguna, apabila hasil pengujian (testing) sudah bisa dianggap memenuhi kebutuhan dari pengguna.

\section{A. Pengujian Black Box}

Pengujian black box yang akan dilakukan dapat ditampilkan sebagai berikut :

Tabel 1. Hasil Black Box

\begin{tabular}{|c|l|c|c|}
\hline Input & \multicolumn{1}{|c|}{ Proses } & Output & $\begin{array}{c}\text { Hasil } \\
\text { uji }\end{array}$ \\
\hline $\begin{array}{c}\text { Tombol } \\
\text { Simpan }\end{array}$ & $\begin{array}{l}\text { Pengguna } \\
\text { menginput data } \\
\text { kemudian klik } \\
\text { tombol simpan }\end{array}$ & $\begin{array}{c}\text { Data } \\
\text { tersimpan }\end{array}$ & Sesuai \\
\hline $\begin{array}{c}\text { Tombol } \\
\text { Hapus }\end{array}$ & $\begin{array}{l}\text { Pengguna } \\
\text { mengklik } \\
\text { tombol delete } \\
\text { pada data table }\end{array}$ & Data & \\
\hline $\begin{array}{c}\text { Tombol } \\
\text { Reset }\end{array}$ & $\begin{array}{l}\text { Pengguna } \\
\text { mengklik }\end{array}$ & $\begin{array}{l}\text { Membatalka } \\
\text { nemai }\end{array}$ \\
\hline
\end{tabular}

\begin{tabular}{|c|c|c|c|}
\hline & tombol Reset & & \\
\hline $\begin{array}{l}\text { Tombol } \\
\text { Perbarui }\end{array}$ & $\begin{array}{l}\text { Pengguna } \\
\text { mengklik } \\
\text { tombol Edit } \\
\text { pada datatable } \\
\text { kemudian } \\
\text { merubah } \\
\text { konten pada } \\
\text { form edit lalu } \\
\text { klik tombol } \\
\text { perbarui }\end{array}$ & $\begin{array}{c}\text { Data } \\
\text { diperbarui }\end{array}$ & Sesuai \\
\hline $\begin{array}{c}\text { Tombol } \\
\text { Cari }\end{array}$ & $\begin{array}{l}\text { Pengguna } \\
\text { mengetik kata } \\
\text { kunci pada } \\
\text { kolom } \\
\text { pencarian }\end{array}$ & $\begin{array}{c}\text { Mencari } \\
\text { Data }\end{array}$ & Sesuai \\
\hline
\end{tabular}

User Acceptance Testing adalah proses pengujian untuk mendapatkan konfirmasi bahwa sebuah sistem memenuhi yang disepakati persyaratan. Dalam pengembangan perangkat lunak, User Acceptance Testing adalah salah satu tahap akhir proyek dan sering terjadi sebelum klien atau pelanggan menerima sistem baru. Dibawah ini adalah keterangan bobot nilai pertanyaan kuisioner :
a. Sangat Setuju $=5$
b. Setuju Sekali $\quad=4$
c. Setuju =3
d. Cukup Setuju $=2$
e. Tidak Setuju $\quad=1$

Analisa hasil kuesioner dilakukan dengan memberikan 4 pertanyaan mengenai aplikasi ini kepada 10 orang responden, dengan kata lain aplikasi ini diujikan langsung kepada pengguna aplikasi ini, pertanyaan kuisioner adalah sebagai berikut:

1. Setujukah anda dengan sistem informasi manajemen berbasis e-commerce dalam pengelolaan dan pemasaran hasil industri rumah tangga?

Tabel 2. Hasil Kuisioner Pertanyaan Pertama

\begin{tabular}{|c|c|c|c|c|}
\hline 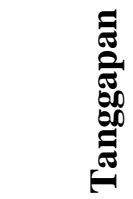 & $\bar{\Xi}$ & $\begin{array}{l}\overrightarrow{8} \\
\stackrel{0}{0}\end{array}$ & $\ddot{\ddot{\theta}}$ & 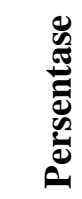 \\
\hline $\begin{array}{l}\text { Sangat } \\
\text { Setuju }\end{array}$ & 3 & 5 & 15 & $38 \%$ \\
\hline Setuju & 3 & 4 & 12 & $31 \%$ \\
\hline
\end{tabular}




\begin{tabular}{|l|l|l|l|c|} 
Sekali & & & & \\
\hline Setuju & 4 & 3 & 12 & $31 \%$ \\
\hline $\begin{array}{l}\text { Cukup } \\
\text { Setuju }\end{array}$ & 0 & 2 & 0 & $0 \%$ \\
\hline $\begin{array}{l}\text { Tidak } \\
\text { Setuju }\end{array}$ & 0 & 1 & 0 & $0 \%$ \\
\hline Total & 10 & - & 39 & $100 \%$ \\
\hline
\end{tabular}

4. Setujukah anda aplikasi ini menghasilkan informasi yang valid dan akurat?

2. Setujukah anda dengan menu-menu didalam aplikasi ini?

Tabel 1. Hasil Kuisioner Pertanyaan Kedua

\begin{tabular}{|c|c|c|c|c|}
\hline 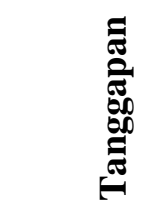 & & $\frac{\overrightarrow{8}}{\hat{0}}$ & $\frac{\dot{s}}{a}$ & 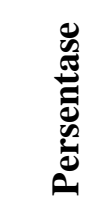 \\
\hline $\begin{array}{l}\text { Sangat } \\
\text { Setuju }\end{array}$ & 3 & 5 & 15 & $38 \%$ \\
\hline $\begin{array}{l}\text { Setuju } \\
\text { Sekali }\end{array}$ & 4 & 4 & 16 & $40 \%$ \\
\hline Setuju & 3 & 3 & 9 & $23 \%$ \\
\hline $\begin{array}{l}\text { Cukup } \\
\text { Setuju }\end{array}$ & 0 & 2 & 0 & $0 \%$ \\
\hline $\begin{array}{l}\text { Tidak } \\
\text { Setuju }\end{array}$ & 0 & 1 & 0 & $0 \%$ \\
\hline Total & 10 & - & 40 & $100 \%$ \\
\hline
\end{tabular}

3. Setujukah anda tampilan dari aplikasi ini mudah dipahami?

Tabel 4. Hasil Kuisioner Pertanyaan Ketiga

\begin{tabular}{|c|c|c|c|c|}
\hline 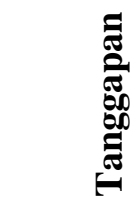 & 趌 & $\frac{\overrightarrow{0}}{\circ}$ & $\frac{\ddot{0}}{\ddot{a}}$ & 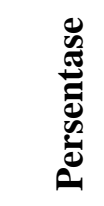 \\
\hline $\begin{array}{l}\text { Sangat } \\
\text { Setuju }\end{array}$ & 2 & 5 & 10 & $26 \%$ \\
\hline $\begin{array}{l}\text { Setuju } \\
\text { Sekali }\end{array}$ & 4 & 4 & 16 & $42 \%$ \\
\hline Setuju & 4 & 3 & 12 & $32 \%$ \\
\hline $\begin{array}{l}\text { Cukup } \\
\text { Setuju }\end{array}$ & 0 & 2 & 0 & $0 \%$ \\
\hline $\begin{array}{l}\text { Tidak } \\
\text { Setuju }\end{array}$ & 0 & 1 & 0 & $0 \%$ \\
\hline Total & 10 & - & 38 & $100 \%$ \\
\hline
\end{tabular}

Tabel 2. Hasil Kuisioner Pertanyaan Keempat

\begin{tabular}{|c|c|c|c|c|}
\hline 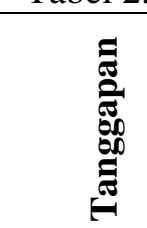 & 疍 & $\begin{array}{l}\overrightarrow{0} \\
\stackrel{0}{0} \\
\text { Q }\end{array}$ & $\frac{\dot{a}}{a}$ & 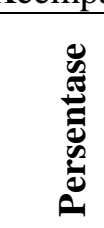 \\
\hline $\begin{array}{l}\text { Sangat } \\
\text { Setuju }\end{array}$ & 2 & 5 & 10 & $26 \%$ \\
\hline $\begin{array}{l}\text { Setuju } \\
\text { Sekali }\end{array}$ & 5 & 4 & 20 & $51 \%$ \\
\hline Setuju & 3 & 3 & 9 & $23 \%$ \\
\hline $\begin{array}{l}\text { Cukup } \\
\text { Setuju }\end{array}$ & 0 & 2 & 0 & $0 \%$ \\
\hline $\begin{array}{l}\text { Tidak } \\
\text { Setuju }\end{array}$ & 0 & 1 & 0 & $0 \%$ \\
\hline Total & 10 & - & 39 & $100 \%$ \\
\hline
\end{tabular}

Untuk user aceptance pada penelitian ini menggunakan sampel data sebanyak 10 orang, dengan hasil sebagai berikut:

Tabel 3. Hasil Kuisioner User Acceptance

\begin{tabular}{|c|c|c|c|c|c|c|}
\hline \multirow{2}{*}{ No. } & \multirow{2}{*}{ Responden } & \multicolumn{4}{|c|}{ Pertanyaan ke- } & \multirow{2}{*}{ Jumlah } \\
\cline { 2 - 6 } & & $\mathbf{1}$ & $\mathbf{2}$ & $\mathbf{3}$ & $\mathbf{4}$ & \\
\hline $\mathbf{1}$ & $\mathbf{1}$ & 4 & 4 & 3 & 5 & 16 \\
\hline $\mathbf{2}$ & $\mathbf{2}$ & 3 & 5 & 4 & 3 & 15 \\
\hline $\mathbf{3}$ & $\mathbf{3}$ & 4 & 5 & 3 & 4 & 16 \\
\hline $\mathbf{4}$ & $\mathbf{4}$ & 3 & 4 & 5 & 3 & 15 \\
\hline $\mathbf{5}$ & $\mathbf{5}$ & 5 & 4 & 3 & 4 & 16 \\
\hline $\mathbf{6}$ & $\mathbf{6}$ & 4 & 3 & 3 & 4 & 14 \\
\hline $\mathbf{7}$ & $\mathbf{7}$ & 5 & 3 & 4 & 3 & 15 \\
\hline $\mathbf{8}$ & $\mathbf{8}$ & 5 & 3 & 4 & 5 & 17 \\
\hline $\mathbf{9}$ & $\mathbf{9}$ & 3 & 5 & 4 & 4 & 16 \\
\hline $\mathbf{1 0}$ & $\mathbf{1 0}$ & 3 & 4 & 5 & 4 & 16 \\
\hline
\end{tabular}

Untuk mengetahui validitas dari aplikasi ini, perlu dilakukan penghitungan validitas, validitas yang dihitung adalah data hasil kuisioner karyawan, dan data terlampir di daftar lampiran, perhitungan data validitas menggunakan rumus:

$\mathrm{r}_{\mathrm{xy}}=\frac{n \sum X Y-\left(\sum X\right)\left(\sum Y\right)}{\sqrt{\left\{n \sum X^{2}-\left(\sum X^{2}\right)^{2}\right\}\left\{n \sum Y^{2}-\left(\sum Y^{2}\right)^{2}\right\}}}$

Keterangan : 
$\mathrm{r}_{\mathrm{xy}} \quad$ : Koefisien korelasi

$\mathrm{n} \quad$ : Jumlah responden

$\mathrm{x} \quad$ : Skor tiap pertanyaan

y : Skor hasil seluruh pertanyaan

Lalu untuk menguji signifikan hasil korelasi, digunakan uji-t. Adapun kriteria untuk menentukan signifikan dengan membandingkan nilai t-hitung dan t-tabel. Jika t-hitung > t-tabel, maka dapat disimpulkan bahwa pertanyaan tersebut valid. Rumus mencari t-hitung yang digunakan adalah :

$t_{\text {hitung }}=\frac{r_{\mathrm{xy}} \sqrt{n-2}}{\sqrt{1-r_{x y}{ }^{2}}}$

Perhitungannya adalah sebagai berikut :

Tabel 4. Hasil Perhitungan Validitas

\begin{tabular}{|c|c|c|c|c|c|c|}
\hline \multirow[b]{2}{*}{ z } & \multirow{2}{*}{ 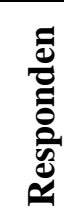 } & \multicolumn{4}{|c|}{ Pertanyaan ke- } & \multirow[b]{2}{*}{$\underline{\Xi}$} \\
\hline & & 1 & 2 & 3 & 4 & \\
\hline 1 & 1 & 4 & 4 & 3 & 5 & 16 \\
\hline 2 & 2 & 3 & 5 & 4 & 3 & 15 \\
\hline 3 & 3 & 4 & 5 & 3 & 4 & 16 \\
\hline 4 & 4 & 3 & 4 & 5 & 3 & 15 \\
\hline 5 & 5 & 5 & 4 & 3 & 4 & 16 \\
\hline 6 & 6 & 4 & 3 & 3 & 4 & 14 \\
\hline 7 & 7 & 5 & 3 & 4 & 3 & 15 \\
\hline 8 & 8 & 5 & 3 & 4 & 5 & 17 \\
\hline 9 & 9 & 3 & 5 & 4 & 4 & 16 \\
\hline 10 & 10 & 3 & 4 & 5 & 4 & 16 \\
\hline \multicolumn{2}{|c|}{ Total } & 39 & 40 & 38 & 39 & \\
\hline \multicolumn{2}{|c|}{$\mathbf{r}_{\mathrm{xy}}$} & 0.241 & 0.161 & 0.033 & 0.643 & \\
\hline \multicolumn{2}{|c|}{$\mathbf{t}_{\text {hitung }}$} & 0.702 & 0.462 & 0.095 & 2.374 & \\
\hline \multicolumn{2}{|c|}{$\begin{array}{c}\mathbf{t}_{\text {tabel }} \\
(\mathbf{9 5 \%}, \\
\mathbf{1 0})\end{array}$} & \multicolumn{4}{|c|}{1.740} & \\
\hline \multicolumn{2}{|c|}{ Ket } & \multicolumn{4}{|c|}{ Valid } & \\
\hline \multicolumn{2}{|c|}{$\begin{array}{c}\text { Jumlah } \\
\text { valid }\end{array}$} & \multicolumn{4}{|c|}{4} & \\
\hline
\end{tabular}

Hasil yang didapat dari perhitungan tersebut adalah bahwa 4 pertanyaan bernilai valid dan tidak ada pertanyaan bernilai tidak valid. Selanjutnya akan dilakukan uji reliabilitas. Dalam melakukan uji reliabilitas ada beberapa langkah yang harus dilakukan yaitu sebagai berikut :

1. Mencari harga variasi total dengan rumus : $\sigma_{b}^{2}=\frac{\sum X^{2}-\frac{\left(\sum X\right)^{2}}{n}}{n}$

2. Menentukan besar varians total dengan rumus :

$$
\sigma_{t}^{2}=\frac{\sum Y^{2}-\frac{\left(\sum Y\right)^{2}}{n}}{n} \text {. }
$$

3. Menghitung koefisien reliabilitas dengan rumus Alpha :

$r_{11}=\left[\frac{k}{k-1}\right]\left[1-\frac{\sigma_{b}^{2}}{\sigma_{t}^{2}}\right]$

Maka perhitungannya sebagai berikut :

Tabel 5. Hasil Perhitungan Realibilitas

\begin{tabular}{|c|c|c|c|c|c|c|}
\hline \multirow[b]{2}{*}{$\stackrel{0}{z}$} & \multirow{2}{*}{ 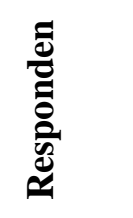 } & \multicolumn{4}{|c|}{ Pertanyaan ke- } & \multirow[b]{2}{*}{$\bar{\Xi}$} \\
\hline & & 1 & 2 & 3 & 4 & \\
\hline 1 & 1 & 4 & 4 & 3 & 5 & 16 \\
\hline 2 & 2 & 3 & 5 & 4 & 3 & 15 \\
\hline 3 & 3 & 4 & 5 & 3 & 4 & 16 \\
\hline 4 & 4 & 3 & 4 & 5 & 3 & 15 \\
\hline 5 & 5 & 5 & 4 & 3 & 4 & 16 \\
\hline 6 & 6 & 4 & 3 & 3 & 4 & 14 \\
\hline 7 & 7 & 5 & 3 & 4 & 3 & 15 \\
\hline 8 & 8 & 5 & 3 & 4 & 5 & 17 \\
\hline 9 & 9 & 3 & 5 & 4 & 4 & 16 \\
\hline 10 & 10 & 3 & 4 & 5 & 4 & 16 \\
\hline \multicolumn{2}{|c|}{ Var Item } & \multicolumn{4}{|c|}{0.7670 .6670 .622 p.544 } & \\
\hline \multicolumn{2}{|c|}{$\square$ VAR ITEM } & \multicolumn{4}{|c|}{2.522} & \\
\hline \multicolumn{2}{|c|}{$\square$ VAR TOTAL } & \multicolumn{4}{|c|}{4.678} & \\
\hline \multicolumn{2}{|c|}{ RELIABILITAS } & \multicolumn{4}{|c|}{0.654} & \\
\hline
\end{tabular}

Di dapat nilai Alpha Cronbach adalah 0,654 dengan jumlah pertanyaan 4 buah. Alpha Cronbach $=0,654$ terletak diantara 0,60 hingga 0,80 sehingga tingkat reliabilitasnya adalah reliabel. Untuk lebih jelasnya tingkat reliabilitas berdasarkan nilai Alpha dapat dilihat pada tabel dibawah ini.

Tabel 6.Tingkat Reliabilitas berdasarkan Alpha

\begin{tabular}{|c|c|}
\hline Alpha & Tingkat Reliabilitas \\
\hline $0,00 \mathrm{~s} / \mathrm{d} 0,20$ & Kurang Reliabel \\
\hline$>0,20 \mathrm{~s} / \mathrm{d} 0,40$ & Agak Reliabel \\
\hline$>0,40 \mathrm{~s} / \mathrm{d} 0,60$ & Cukup Reliabel \\
\hline
\end{tabular}




\begin{tabular}{|c|c|}
$>0,60 \mathrm{~s} / \mathrm{d} 0,80$ & Reliabel \\
\hline$>0,80 \mathrm{~s} / \mathrm{d} 1,00$ & Sangat Reliabel \\
\hline
\end{tabular}

Gambar 18. dibawah menerangkan hasil dari jawaban responden terhadap empat pertanyaan yang ada pada kuisioner dan Gambar 19. Menerangkan hasil dari jawaban responden terhadap empat pertanyaan yang ada pada kuisioner.

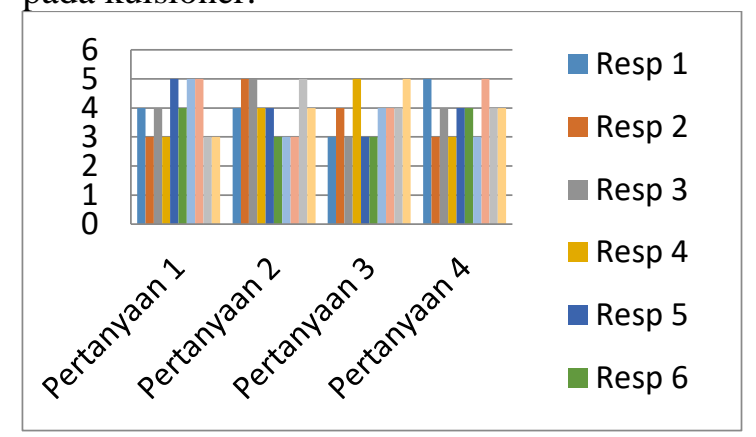

Gambar 18. Grafik Hasil Jawaban

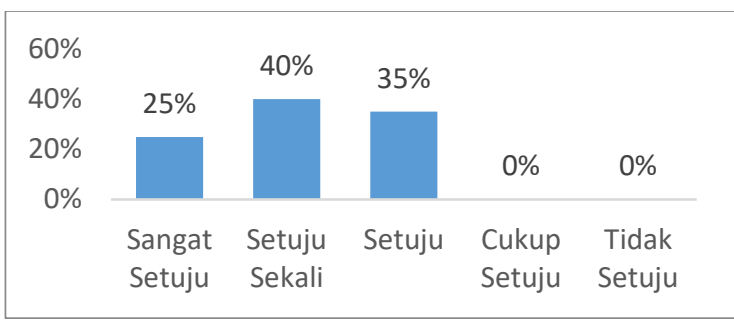

Gambar 19. Grafik Hasil Jawaban Kuisio

\section{KESIMPULAN}

Berdasarkan hasil penelitian yang telah dilakukan dapat diambil beberapa kesimpulan antara lain:

1. Sistem Informasi Manajemen berbasis ecommerce sangat memberikan manfaat baik bagi penjual maupun pembeli, karena semua terkomputerisasi secara online.

2. Sistem pemasaran online yang dijalankan memberikan efek positif pada hasil penjualan dan efektifnya pengelolaan perdangaan baik itu stok, harga dan supplier. hal ini disebabkan karena sistem yang dibuat berbasis sistem informasi manajemen.

3. mudahnya penggunaan transaksi online oleh calon pembeli dalam melakukan transaksi. Selain dapat melihat barang secara tergambar, calon pembeli juga dapat berinteraksi langsung dengan admin penjual dengan video call
4. Hasil Pengujian yang dilakukan baik dengan metode blackbox atau user acceptance didapatkan hasil yang sangat baik tentang sistem informasi manajemen.

\section{DAFTAR PUSTAKA}

Arief, M. R. (2011). Pemrograman Web Dinamis Menggunakan PHP dan MySQL. Yogyakarta: Andi.

Dillman, D. A., Smyth, J. D., \& Christian, L. M. (2014). Internet, phone, mail, and mixed-mode surveys: the tailored design method. John Wiley \& Sons.

Hasanah, U. (2013). Sistem Informasi Penjualan On_Line Pada Toko Kreatif Suncom Pacitan. IJNS-Indonesian Journal on Networking and Security, 4(3).

Irmawati, D. (2011). Pemanfaatan e-commerce dalam dunia bisnis. Orasi Bisnis, 13-20.

Jauhari, J. (2014). Upaya pengembangan usaha kecil dan menengah (UKM) dengan memanfaatkan e-commerce. Jurnal Sistem Informasi, 2(1).

Kosasi, S. (2015). Perancangan Sistem ECommerce Untuk Memperoleh Pasar Produk Oleh-oleh Khas Pontianak. SNASTIA, 110-119.

Maryama, S. (2013). Penerapan E-Commerce Dalam Meningkatkan Daya Saing Usaha. Liquidity, 73-79.

Maharsi, S. (2004). Pengaruh Perkembangan Teknologi Informasi Terhadap Bidang Akuntansi Manajemen. Jurnal Akuntansi dan keuangan, 2(2), pp-127.

Saputro, H. W. (2007). Pengertian Website, Web Hosting dan Domain Name.

Setiyadi, A., \& Triyono, R. A. (2014). Pembangunan Website E-Commerce Dengan Sistem Informasi Transaksi Berbasis SMS Gateway PAda Toko Aska. IJNS, 30-36. 
